\title{
Evaluasi Kesiapan Rumah Sakit Umum Daerah Kabupaten Brebes Menuju Badan Layanan Umum Daerah
}

\author{
Sri Nani Purwaningrum \\ Dosen Jurusan PIKES Poltekkes Kemenkes Tasikmalaya.
}

\begin{abstract}
Abstrak
Paradigma rumah sakit mengalami perubahan dan merupakan badan usaha yang mempunyai banyak unit bisnis strategis, sehingga membutuhkan konsep manajemen yang tepat. Rumah sakit pemerintah mulai bertransformasi menjadi Pola Pengelolaan Keuangan Badan Layanan Umum Daerah (PPK-BLUD), dimana hal ini menjadi prioritas berbagai rumah sakit, termasuk RSUD Brebes. Badan Layanan Umum (BLU) alternatif solusi untuk mengadopsi sistem baru pengelolaan keuangan transparan, akuntabel dan mandiri yang muaranya pada kualitas pelayanan. Penelitian ini bertujuan untuk mengetahui kesiapan RSUD Brebes, dukungan Pemerintah Daerah dan Legislatif, serta faktor pendukung dan penghambat yang mempengaruhi kesiapan RSUD Brebes menuju BLUD. Jenis penelitian adalah kualitatif dengan desain studi kasus tunggal pendekatan deskriptif. Subjek penelitian adalah pelaksanaan pengelolaan keuangan di RSUD Brebes. Informan penelitian diklasifikasikan menjadi dua yaitu stakeholder internal dan eksternal RSUD Brebes yang berjumlah 12 orang. Setelah dilakukan indepth interview, dilanjutkan membuat transkrip dan mereduksi hasil wawancara. Selanjutnya interpretasi hasil reduksi untuk mengidentifikasi kesiapan RSUD Brebes menuju BLUD. Hasil identifikasi dokumen persyaratan administratif diperoleh sebesar 93,65, masuk kategori status BLUD Penuh dengan kriteria memuaskan dan layak ditetapkan menjadi PPK-BLUD. Persyaratan menuju PPK-BLUD sudah dipersiapkan oleh RSUD Brebes, Pemda dan Legislatif sangat mendukung terhadap kesiapan RSUD Brebes menuju BLUD.
\end{abstract}

Kata Kunci : Evaluasi Kesiapan Menuju BLUD, PPK-BLUD, Persyaratan BLUD.

\section{PENDAHULUAN}

Paradigma jasa pelayanan rumah sakit dewasa ini sudah mengalami perubahan yang mendasar dan merupakan sebuah badan usaha yang mempunyai banyak unit bisnis strategis, sehingga membutuhkan penanganan dengan konsep manajemen yang tepat (Ristrini, 2005). Banyak rumah sakit tidak lagi dikelola oleh yayasan nirlaba, tetapi diselenggarakan oleh perseroan terbatas, perusahaan jawatan dan bentuk badan hukum lainnya yang tidak lepas dari aspek bisnis. Bahkan rumah sakit pemerintah pun dewasa ini sedang bertransformasi menjadi perusahaan jawatan yang merupakan suatu bentuk pengelolaan korporasi (Soeroso, 2003).

Salah satu regulasi yang mendasari terjadinya transformasi pengelolaan manajemen rumah sakit dewasa ini adalah dengan terbitnya produk Undang-Undang nomor 1 tahun 2004 tentang Perbendaharaan Negara yang memungkinkan instansi pemerintah membentuk Badan Layanan Umum (BLU). Peluang ini secara khusus disediakan kesempatannya bagi satuan kerja pemerintah yang melaksanakan tugas operasional pelayanan publik, seperti layanan kesehatan, pendidikan, layanan kawasan dan lisensi, untuk membedakannya dari fungsi pemerintah sebagai regulator dan penentu kebijakan. PPK-BLU adalah pola pengelolaan keuangan yang memberikan fleksibilitas berupa keleluasaan untuk menerapkan praktek-praktek bisnis yang sehat untuk 
meningkatkan pelayanan kepada masyarakat dalam rangka memajukan kesejahteraan umum dan mencerdaskan kehidupan bangsa. Namun demikian, BLU dikendalikan secara ketat, baik dalam perencanaan dan penganggarannya maupun pertanggungjawabannya.

Tujuan BLU sesuai PP 23 tahun 2005 tentang pengelolaan keuangan BLU, adalah memberikan pelayanan kepada masyarakat berupa penyediaan barang dan atau jasa yang dijual tanpa mengutamakan keuntungan BLU dalam melaksanakan kegiatannya didasarkan pada prinsip efisiensi dan produktivitas. Pendanaan BLU sudah tidak sepenuhnya bersumber dari APBN dan APBD. BLU juga dapat mengelola dana masyarakat yang dimanfaatkan secara langsung untuk memberikan pelayanan kepada pelanggan semaksimal mungkin, sehingga kepuasan pelanggan tetap terjaga. Sehubungan dengan privilege yang diberikan dan tuntutan khusus yang diharapkan dari BLU, keberadaannya harus diseleksi dengan tata kelola khusus. Sebagai rumah sakit pemerintah, RSUD Brebes harus tetap menjaga dan meningkatkan kualitas jasa pelayanan agar tetap survive di tengahtengah perkembangan rumah sakit swasta yang pesat di wilayah Kabupaten Brebes dan daerah sekitarnya.

Berdasarkan telaah dokumen dan studi pendahuluan penulis, diketahui ada 6 (enam) RSU swasta di wilayah Kabupaten Bebes yang melaporkan pencapaian kinerja pelayanannya setiap tahun. Ditinjau dari segi kinerja pelayanan RSUD Brebes dibandingkan dengan 6 (enam) RSU swasta lainnya selama kurun waktu tiga tahun terakhir, (tahun 2097 - 2009), secara umum menduduki urutan pertama dan berada pada batas standar mutu nasional kinerja pelayanan rumah sakit. Capaian kinerja pelayanan RSUD Brebes tahun 2009 yaitu Bed Occupancy Rate $(B O R)$ dengan nilai sebesar 57.4, Length of Stay (LOS) sebesar 4.59, Turn Over Interval (TOI) sebesar 2.73, Gross Death Rate (GDR) sebesar 37.3 dan Net Death Rate (NDR) sebesar 2.7 dengan jumlah tempat tidur sebesar 215. Trend kunjungan pasien rawat jalan dan rawat inap cenderung mengalami peningkatan, meskipun nilainya masih fluktuatif. Ketersediaan sumber daya manusia baik dari jenis ketenagaan medis dan non medis sebagian besar sudah memenuhi standar RSU tipe C, meskipun untuk tenaga medis masih perlu penambahan. Trend kontribusi pendapatan RSUD Brebes terhadap PAD Kabupaten Brebes cenderung meningkat, tahun 2007 sebesar $12.1 \%$, tahun 2008 sebesar $21.3 \%$ dan tahun 2009 sebesar $32 \%$. Mutu asuhan kesehatan sebuah rumah sakit akan selalu terkait dengan struktur, proses dan outcome sistem pelayanan rumah sakit tersebut. Mutu asuhan pelayanan rumah sakit juga dapat dikaji dari tingkat pemanfaatan sarana pelayanan oleh masyarakat, mutu pelayanan dan tingkat efisiensi rumah sakit (Muninjaya, 2004).

Ditinjau dari kondisi di atas dapat digambarkan bahwa RSUD Brebes mempunyai peluang untuk meraih pangsa pasar yang berpotensi lebih banyak lagi di tahun mendatang. Namun di sisi lain ditemukan beberapa permasalahan yang dihadapi dalam pengelolaan keuangan yaitu: pengelolaan keuangan (billing system, pencatatan, pembuatan laporan) masih manual; tenaga pengelola keuangan jumlahnya belum memadai dan belum ada yang memenuhi kompetensi profesional akuntansi; belum ada standar akuntansi yang baku untuk RSUD; kurangnya transfer pengetahuan antar pegawai dan pembagian tugas yang kurang proporsional mengakibatkan adanya overlapping tugas; turn over pegawai tidak sesuai kompetensinya atau kebutuhan beban tugas; pendapatan cash rumah sakit harus disetor langsung ke kas daerah dan pengembalian retribusi dari kas daerah seringkali terlambat.

Beberapa permasalahan tersebut mengakibatkan terganggunya operasional pelayanan rumah sakit. Dengan bentuk pengelolaan sebagai Satuan Kerja Perangkat Daerah (SKPD) yang berjalan 
selama ini, mengakibatkan pendapatan fungsional rumah sakit tidak dapat dipergunakan secara langsung karena harus mengikuti mekanisme APBD yaitu dengan mendapatkan persetujuan pihak legislatif dan eksekutif terlebih dahulu. Dengan melihat kemampuan yang dimiliki saat ini dan permasalahan yang dihadapi serta dukungan regulasi, maka paradigma BLUD

\section{METODE PENELITIAN}

Rancangan Penelitian ini adalah penelitian kualitatif deskriptif dengan desain studi kasus tunggal terpancang (Yin, 2005). Alasan pemilihan desain penelitian tersebut adalah untuk menggambarkan tentang fenomena atau isu penting yang bersifat holistik (menyeluruh, tidak dapat dipisahpisahkan), sehubungan dengan kesiapan RSUD Brebes menuju BLUD.

Subjek dalam penelitian ini adalah pelaksanaan pengelolaan keuangan di RSUD Brebes. Informan dalam penelitian ini dipilih sesuai kriteria inklusi dan ekslusi secara purposive sampling. Sampel berjumlah 15 orang informan yang menjadi responden dengan kriteria sebagai berikut :

a. Dapat menjawab dan komunikatif

b. Bersedia menjadi responden Variabel penelitian ini terdiri dari :

1. Komitmen dan kepemimpinan

- Komitmen stakeholder internal

- Kepemimpinan senior

2. Persyaratan BLUD

- Persyaratan substantif

- Persyaratan teknis

- Persyaratan administratif

3. Dukungan stakeholder

- Stakeholder internal

- Stakeholder eksternal

4. Faktor-faktor yang berpengaruh

- Faktor pendorong

- Faktor penghambat

5. Kesiapan menjadi BLUD

Pengumpulan data dilakukan oleh peneliti untuk mendapatkan keterangan yang luas dan mendalam dari responden maka digunakan metode wawancara mendalam dengan teknik rapport (menghubungkan) dan probing menjadi alternatif solusi bagi RSUD Brebes. $\mathrm{Hal}$ ini menjadi penting bagi RSUD Brebes dalam upaya membidik prospek masa depan untuk mendukung pendanaan operasional RSUD Brebes yang muaranya pada peningkatan kualitas pelayanan. Berdasarkan latar belakang tersebut di atas, bagaimana kesiapan RSUD Brebes menuju Badan Layanan Umum Daerah (BLUD) ?.

(pendalaman). Pada saat wawancara berlangsung, responden diberi keleluasaan untuk menentukan alur cerita bergulir. Selama proses wawancara digunakan tape recorder untuk merekam agar mempermudah pengumpulan data. Untuk tujuan optimalisasi proses, peneliti membatasi wawancara dilakukan hanya untuk 2 informan setiap harinya, dengan terlebih dahulu membuat kesepakatan jadwal wawancara dan memberikan pedoman wawancara untuk dipelajari.

Instrumen pengumpulan data yang digunakan dalam penelitian ini adalah pedoman wawancara semi terstruktur, check list dokumen, dan observasi. Untuk wawancara mendalam semi terstruktur mula-mula interviewer menanyakan beberapa pertanyaan yang sudah terstruktur, kemudian satu per satu diperdalam untuk menggali keterangan lebih lanjut. Dengan demikian jawaban yang diperoleh dapat meliputi semua variabel, dengan keterangan yang lengkap dan mendalam.

Sumber data dalam penelitian ini terdiri dari data primer dan data sekunder. Data primer diperoleh dari observasi dan wawancara mendalam (indepth interview). Data sekunder diperoleh melalui pengamatan/penelusuran dokumendokumen administrasi keuangan, peraturan internal rumah sakit dan peraturan pemerintah. Data-data yang dikumpulkan meliputi realisasi anggaran pendapatan belanja daerah (APBD), retribusi pendapatan, laporan keuangan, catatancatatan lain yang berhubungan dengan administrasi keuangan, kinerja pelayanan 
rumah sakit, data SDM dan dokumen pendukung lain.

Data yang terkumpul disajikan dalam bentuk matriks dan narasi informasi dari hasil wawancara, pengamatan di lapangan dan didukung dokumentasi administrasi. Beberapa pernyataan informan dari hasil wawancara mendalam disajikan dalam bentuk matriks, dengan tahapan pertama membuat transkrip dengan kalimat naratif sesuai dengan hasil wawancara. Kedua, mereduksi kalimat untuk menarik intisari atau temuan penelitian. Ketiga, mempertegas hasil temuan atau intisari dengan menggunakan format matriks Miles. Kemudian dilakukan analisis grounded pada transkrip wawancara. Tahap selanjutnya adalah analisis kognitif yang meliputi

\section{HASIL PENELITIAN}

Variabel yang diteliti di RSUD Brebes ini merupakan variabel criterion yang meliputi: Komitmen dan Kepemimpinan, Persyaratan BLUD, Dukungan stakeholder, Faktor-faktor pemahaman

(comprehending), mengumpulkan dan mempersatukan data (synthesizing). Kemudian dilakukan pemeriksaan keabsahan data dengan metode triangulasi yaitu triangulasi data melalui verifikasi dengan informan, triangulasi sumber digali dari informan yang berbeda dan triangulasi metode yaitu wawancara mendalam dan telaah dokumen. Penyajian data dilakukan secara deskriptif. Hasil pengolahan data disajikan secara naratif dan intisari transkrip wawancara, tabel, grafik dan gambar. Untuk mendapatkan informasi peneliti menanyakan kesediaan responden terlebih dahulu sebelum diwawancarai, selanjutnya disampaikan maksud dan tujuan penelitian serta menjamin kerahasiaan responden.

yang berpengaruh. Hasil penelitian dan pembahasan dari masing-masing variabel diuraikan sebagai berikut :

\section{Komitmen dan Kepemimpinan}

Tabel 1. Hasil evaluasi Kesiapan RSUD Brebes menuju BLUD ( Variabel Komitmen dan Kepemimpinan)

\begin{tabular}{|c|c|c|c|}
\hline $\begin{array}{l}\text { Variabel kesiapan } \\
\text { RSUD Brebes } \\
\text { menuju BLUD }\end{array}$ & $\begin{array}{l}\text { Standar/ Indikator kesiapan } \\
\text { menjadi BLUD }\end{array}$ & $\begin{array}{c}\text { Hasil identifikasi } \\
\text { (kondisi nyata/resume hasil analisis } \\
\text { data, wawancara dokumen) }\end{array}$ & Gap \\
\hline \multicolumn{4}{|l|}{$\begin{array}{l}\text { 1. Komitmen dan } \\
\text { Kepemimpinan }\end{array}$} \\
\hline $\begin{array}{ll}1.1 . & \text { Komitmen } \\
& \text { stakeholder } \\
\text { internal }\end{array}$ & $\begin{array}{l}\text { - } \text { Kesamaan mindset/kepercayaan } \\
\text { kuat terhadap tujuan organisasi } \\
\text { menuju BLUD } \\
\text { - } \text { Keterlibatan/kesediaan stakeholder } \\
\text { internal untuk memberikan } \\
\text { tenaganya atas nama organisasi } \\
\text { dalam rangka menuju BLUD }\end{array}$ & $\begin{array}{l}\text { Stakeholder internal mengetahui, } \\
\text { memahami dan menyetujui rencana } \\
\text { BLUD RSUD Brebes } \\
\text { Membentuk tim BLUD RSUD Brebes, } \\
\text { advokasi dan sosialisasi internal dan } \\
\text { eksternal, studi banding dan } \\
\text { pendampingan dengan BPKP }\end{array}$ & \\
\hline $\begin{array}{ll}\text { 1.2. } & \text { Kepemimpinan } \\
\text { Senior }\end{array}$ & $\begin{array}{l}\text { - Arsitek penyusun grand design } \\
\text { BLUD } \\
\text { - Komunikasi dua arah (sosialisasi } \\
\text { dan advokasi BLUD) dengan } \\
\text { stakeholder internal dan eksternal } \\
\text { - Sistem kepemimpinan mampu } \\
\text { mengembangkan dan berperan } \\
\text { sebagai penggerak dalam } \\
\text { mencapai tujuan transformasi } \\
\text { sistem manajemen menuju BLUD } \\
\text { - Menetapkan target kinerja } \\
\text { organisaasi dalam mencapai tujuan } \\
\text { BLUD }\end{array}$ & 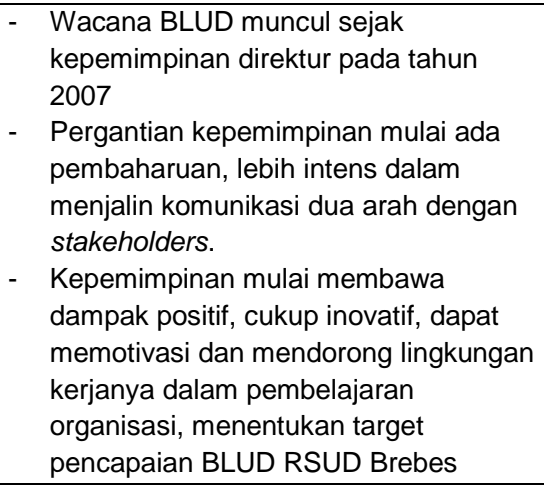 & \\
\hline
\end{tabular}




\section{Persyaratan BLUD}

Tabel 2. Hasil Evaluasi Kesiapan RSUD Brebes menuju BLUD ( Variabel Persyaratan BLUD )

\begin{tabular}{|c|c|c|c|}
\hline $\begin{array}{l}\text { Variabel kesiapan } \\
\text { RSUD Brebes } \\
\text { menuju BLUD } \\
\end{array}$ & $\begin{array}{l}\text { Standar/ indikator kesiapan menjadi } \\
\text { BLUD }\end{array}$ & $\begin{array}{c}\text { Hasil identifikasi } \\
\begin{array}{c}\text { (kondisi nyata/resume hasil analisis } \\
\text { data, wawancara dokumen) }\end{array}\end{array}$ & Gap \\
\hline \multicolumn{4}{|l|}{$\begin{array}{ll}\text { 2. } & \text { Persyaratan } \\
\text { BLUD }\end{array}$} \\
\hline $\begin{array}{ll}\text { 2.1. } & \text { Persyaratan } \\
\text { substantif }\end{array}$ & $\begin{array}{l}\text { SKPD atau unit kerja yang } \\
\text { tupoksinya bersifat operasional } \\
\text { dalam menyelenggarakan pelayanan } \\
\text { umum yang menghasilkan semi } \\
\text { barang/jasa publik (quasi public } \\
\text { goods) } \\
\text { Kinerja pelayanan di bidang tugas } \\
\text { pokok dan fungsinya layak dikelola } \\
\text { dan ditingkatkan pencapaiannya } \\
\text { melalui BLU : } \\
\text { - Rata-rata kunjungan pasien rawat } \\
\text { jalan trend nya meningkat setiap } \\
\text { tahunnya } \\
\text { - Trend kinerja pelayanan } \\
\text { menunjukkan kecenderungan naik }\end{array}$ & $\begin{array}{l}\text { RSUD Brebes merupakan institusi } \\
\text { Pemda yang tupoksinya sebagai } \\
\text { provider pelayanan kesehatan } \\
\text { rujukan dan menghasilkan produk } \\
\text { jasa layanan kesehatan. }\end{array}$ & \\
\hline $\begin{array}{ll}\text { 2.2. } & \text { Persyaratan } \\
& \text { teknis }\end{array}$ & & 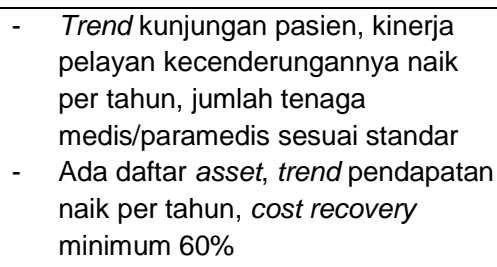 & \\
\hline $\begin{array}{ll}\text { 2.3. } & \text { Persyaratan } \\
& \text { administratif }\end{array}$ & $\begin{array}{ll}\text { - } & \text { Surat pernyataan kesanggupan } \\
\text { untuk meningkatkan kinerja } \\
\text { pelayanan, keuangan dan manfaat } \\
\text { bagi masyarakat } \\
\text { - } & \text { Renstra Bisnis (RSB) } \\
\text { - } & \text { Dokumen Tata Kelola } \\
\text { - } & \text { Standar Pelayanan Minimal (SPM) } \\
\text { - } & \text { Laporan Keuangan } \\
\text { - } & \text { Laporan audit terakhir atau } \\
& \text { pernyataan bersedia untuk diaudit } \\
& \text { secara independen }\end{array}$ & $\begin{array}{ll}\text { - } & \text { Persyaratan administratif sudah } \\
\text { memenuhi/lengkap } \\
\text { - } & \text { Perolehan score nilai sesuai } \\
\text { penilaian dewan penilai tingkat } \\
\text { kabupaten penerapan PPK-BLUD } \\
\text { RSUD Brebes yaitu 87,90 dengan } \\
\text { rekomendasi status BLUD penuh }\end{array}$ & \\
\hline
\end{tabular}

\section{Dukungan Stakeholder}

Tabel 3. Hasil evaluasi Kesiapan RSUD Brebes menuju BLUD ( Variabel Dukungan Stakeholder)

\begin{tabular}{|c|c|c|c|}
\hline $\begin{array}{c}\text { Variabel kesiapan } \\
\text { RSUD Brebes } \\
\text { menuju BLUD }\end{array}$ & $\begin{array}{c}\text { Standar/ indikator kesiapan } \\
\text { menjadi BLUD }\end{array}$ & $\begin{array}{c}\text { Hasil identifikasi } \\
\text { (kondisi nyata/resume hasil analisis } \\
\text { data, wawancara dokumen) }\end{array}$ & Gap \\
\hline $\begin{array}{l}\text { 3. } \begin{array}{l}\text { Dukungan } \\
\text { Stakeholder }\end{array} \\
\text { 3.1. } \begin{array}{l}\text { Stakeholder } \\
\text { internal }\end{array}\end{array}$ & $\begin{array}{l}\text { - } \\
\text { Kesiapan stakeholder internal } \\
\text { terhadap proses menuju } \\
\text { kebijakan BLUD yang }\end{array}$ & $\begin{array}{l}- \text { Langkah-langkah persiapan yang } \\
\text { dilaksanakan sejak tahun 2007 } \\
\text { adalah: }\end{array}$ & $\begin{array}{l}\text { Dalam rentang } \\
\text { waktu tiga } \\
\text { tahun, saat ini }\end{array}$ \\
\hline
\end{tabular}




\begin{tabular}{|c|c|c|c|}
\hline & $\begin{array}{l}\text { dibuktikan dengan } \\
\text { melaksanakan langkah - } \\
\text { langkah persiapan sampai } \\
\text { dengan tercapainya keputusan } \\
\text { menuju BLUD, adanya } \\
\text { dokumen-dokumen pendukung } \\
\text { persyaratan BLUD, melakukan } \\
\text { konsolidasi dengan pihak- } \\
\text { pihak eksternal terkait dengan } \\
\text { BLUD. }\end{array}$ & $\begin{array}{l}\text { - Membentuk tim BLUD RSUD } \\
\text { Brebes } \\
\text { - Mengikuti bintek BLUD } \\
\text { - Studi banding } \\
\text { - Pendampingan penyusunan } \\
\text { persyaratan administratif dengan } \\
\text { BPKP } \\
\text { - Advokasi dan sosialisasi dengan } \\
\text { Pemda/legislatif } \\
\text { - Membentuk dewan penilai BLUD } \\
\text { - Pembekalan Dewan Penilai oleh } \\
\text { konsultan BLUD }\end{array}$ & $\begin{array}{l}\text { pelaksanaan } \\
\text { persiapan } \\
\text { penerapan } \\
\text { PPK-BLUD } \\
\text { RSUD Brebes } \\
\text { baru masuk } \\
\text { pada tahap } \\
\text { penilaian }\end{array}$ \\
\hline $\begin{array}{l}\text { 3.2. } \begin{array}{l}\text { Stakeholder } \\
\text { eksternal }\end{array}\end{array}$ & $\begin{array}{l}\text { Adanya sikap positif/ support } \\
\text { organisasi jajaran eksekutif } \\
\text { dan legislatif terhadap proses } \\
\text { transformasi RSUD menuju } \\
\text { BLUD } \\
\text { - } \quad \text { Adanya keselarasan mind set } \\
\text { terhadap BLUD } \\
\text { - } \quad \begin{array}{l}\text { Kemudahan regulasi dari } \\
\text { Pemda Brebes }\end{array}\end{array}$ & $\begin{array}{l}\text { - Pemda/legislatif mendukung } \\
\text { pembentukan PPK-BLUD RSUD } \\
\text { Brebes } \\
\text { - } \text { Tercapai kesepahaman dan } \\
\text { kesepakatan untuk penilaian } \\
\text { - Pemda Brebes menjamin } \\
\text { kemudahan regulasi jika semua } \\
\text { persyaratan sudah memenuhi } \\
\text { standar }\end{array}$ & \\
\hline
\end{tabular}

\section{Faktor- faktor yang berpengaruh}

Tabel 4. Hasil evaluasi Kesiapan RSUD Brebes menuju BLUD ( Variabel Faktor-faktor yang berpengaruh)

\begin{tabular}{|c|c|c|c|}
\hline $\begin{array}{l}\text { Variabel kesiapan RSUD } \\
\text { Brebes menuju BLUD }\end{array}$ & $\begin{array}{c}\text { Standar/ indikator } \\
\text { kesiapan menjadi BLUD }\end{array}$ & $\begin{array}{c}\text { Hasil identifikasi (kondisi } \\
\text { nyata/resume hasil analisis data, } \\
\text { wawancara dokumen) }\end{array}$ & Gap \\
\hline $\begin{array}{l}\text { 4. Faktor-faktor yang } \\
\text { berpengaruh } \\
\text { - } \text { Faktor -faktor } \\
\text { pendorong dan } \\
\text { penghambat }\end{array}$ & $\begin{array}{l}\text { - Organisasi } \\
\text { - Budaya organisasi } \\
\text { Individual/fokus staf } \\
{ }^{*} \text { Kemampuan dan } \\
\text { keahlian } \\
{ }^{*} \text { Sistem kerja } \\
\text { * Pembelajaran dan } \\
\text { motivasi } \\
\text { * Kesejahteraan dan } \\
\text { kepuasan staf } \\
\text { - Struktur organisasi / job } \\
\text { design } \\
\text { - Sumber daya (SDM, } \\
\text { keuangan, sistem } \\
\text { informasi, teknologi) } \\
\text { - Kepemimpinan } \\
\text { - Penghargaan }\end{array}$ & $\begin{array}{l}\text { - Kompetensi tenaga profesional medis } \\
\text { dan manajemen sudah memenuhi } \\
\text { persyaratan dasar sistem kerja } \\
\text { - SOTK RSUD Brebes belum dapat } \\
\text { mengakomodir secara komprehensif } \\
\text { pelayanan versi BLUD } \\
\text { - Pengelolaan kinerja cukup } \\
\text { mendukung praktik kompensasi } \\
\text { (remunerasi). } \\
\text { - Secara internal perencanaan untuk } \\
\text { suksesi dan rekruitment pegawai } \\
\text { disusun oleh RS, tetapi } \\
\text { pengesahannya menjadi kewenangan } \\
\text { pemda } \\
\text { - Aplikasi SIMRS mendukung } \\
\text { implementasi billing system RS dalam } \\
\text { menerapkan manajemen BLUD } \\
\text { - Mekanisme pengelolaan keuangan } \\
\text { mengacu APBD } \\
\text { - Kepemimpinan saat ini sangat kreatif } \\
\text { dan inovatif terhadap akselerasi } \\
\text { penerapan PPK-BLUD }\end{array}$ & $\begin{array}{l}\text { Kinerja } \\
\text { pelayanan } \\
\text { RSUD Brebes } \\
\text { masih kurang } \\
\text { optimal }\end{array}$ \\
\hline & - Regulasi terkait BLUD & $\begin{array}{l}\text { - Semua persyaratan disusun mengacu } \\
\text { pada regulasi terkait BLUD } \\
\text { - Pemda Brebes menjamin kemudahan } \\
\text { terkait regulasi beberapa persyaratan } \\
\text { pendukung operasionalisasi BLUD }\end{array}$ & \\
\hline
\end{tabular}




\section{PEMBAHASAN}

\section{Komitmen dan Kepemimpinan}

a. Komitmen stakeholder internal

Komitmen merupakan kesetiaan anggota dan pemimpin rumah sakit terhadap organisasinya. Komitmen merupakan proses yang berkelanjutan dengan para anggota organisasi, dimana masing-masing memberikan kontribusi terhadap kemajuan organisasi. Dalam rumah sakit peran komitmen sangat penting sebagai perekat sistem yang telah dibuat bersama. Merujuk pada hasil penelitian, diketahui bahwa komitmen stakeholder RSUD Brebes menuju penerapan PPKBLUD mulai terbentuk. Dari hasil wawancara dengan beberapa stakeholder RSUD Brebes, diperoleh informasi adanya kesepahaman di internal organisasi tentang tujuan BLUD, dan keterlibatan semua lini dalam langkah-langkah persiapan dari awal pembentukan tim internal BLUD sampai pada tahap akhir menjelang penilaian PPKBLUD RSUD Brebes dalam waktu dekat ini. Menurut Luthan, 1996 (cit.Trisnantoro 2005) komitmen tinggi akan menentukan tingkat retensi karyawan dan produktivitas kerja yang baik serta rasa memiliki lembaga di hati karyawan. Dalam hal ini perlu disadari bahwa muncul berbagai faktor komitmen yang perlu dikaji yaitu (1) gaya kepemimpinan; (2) iklim kerja dan kompensasi; (3) faktor-faktor personal.

b. Kepemimpinan senior

Dalam sebuah organisasi, kepemimpinan merupakan hal terpenting yang menentukan pengembangan dan daya saing organisasi. Peran kepemimpinan senior dalam menyusun visi, misi dan nilai serta arah organisasi dapat menentukan eksistensi organisasi. Merujuk pada hasil penelitian, bahwa wacana awal pembentukan PPK-BLUD RSUD Brebes muncul dari direktur pada tahun 2007. Langkah awal yang dilaksanakan yaitu dengan mengikuti bintek BLUD di berbagai tempat, dengan melibatkan beberapa personil RSUD Brebes yang cukup berpotensi. Selanjutnya membentuk tim BLUD RSUD Brebes yang terdiri dari empat pokja yaitu pokja renstra bisnis (RSB), tata kelola, standar pelayanan minimal (SPM) dan laporan keuangan pokok. Tim BLUD tersebut kemudian mengikuti pendampingan penyusunan persyaratan administratif dengan konsultan BPKP pada tahun 2007. Hal ini sudah sesuai dengan teori Duncan et al. (1998) yang mengatakan bahwa visi, misi dan nilai dibentuk oleh kepemimpinan senior, staf terpilih dan orang penting lainnya. Pada era kepemimpinan baru saat ini nilai-nilai dasar organisasi untuk mewujudkan visi dan misi RSUD Brebes mulai terbentuk.

Langkah inovatif yang dilakukan oleh pemimpin puncak mengindikasikan adanya upaya untuk memberikan arahan secara jelas dan merupakan awal komitmen pemimpin untuk membangun dan mengimplementasikan sistem yang menjamin bahwa nilai-nilai organisasi harus dapat dipahami dan dipraktikkan secara konsisten dalam kegiatan operasional. Aspek penting lain adalah komunikasi, sebaik apapun arahan yang ditetapkan, jika tidak dipahami oleh pegawai maka arahan tersebut justru akan menciptakan persepsi dan tindakan yang tumpang tindih dan tidak selaras. Merujuk pada hasil penelitian adanya suksesi kepemimpinan pada pertengahan tahun 2008 dan tahun 2010 ini, banyak terjadi perubahan ke arah perbaikan menajemen rumah sakit.

\section{Persyaratan BLUD}

a. Persyaratan substantif.

RSUD Brebes merupakan institusi milik Pemda yang tupoksinya sebagai provider pelayanan kesehatan rujukan dan produknya adalah jasa layanan kesehatan, hal ini menunjukkan bahwa RSUD Brebes sudah memenuhi persyaratan substantif sebagai PPK-BLUD.

b. Persyaratan teknis.

Merujuk pada hasil penelitian diperoleh data bahwa kinerja layanan RSUD Brebes saat ini layak dikelola dan ditingkatkan pencapaiannya melalui BLU. Indikator pengukurannya adalah data jumlah 
kunjungan pasien IRNA dan IRJA serta kinerja pelayanan yang trendnya menunjukkan kecenderungan naik setiap tahunnya. Indikator pengukuran lainnya adalah kinerja keuangan RSUD Brebes saat ini adalah sehat. Hal ini dibuktikan adanya daftar asset, trend pendapatan rumah sakit yang cenderung naik setiap tahunnya.

c. Persyaratan administratif.

Merujuk pada hasil penelitian, diperoleh informasi bahwa tahap revisi dokumen ini mengacu pada masukanmasukan yang diberikan oleh konsultan pendamping dari UGM dan dewan penilai BLUD RSUD Brebes pada acara pembekalan untuk dewan penilai. Dokumen yang telah direvisi akan dinilai oleh konsultan sesuai pedoman penilaian PPKBLUD dari Departemen Dalam Negeri (Depdagri). Selanjutnya dimintakan rekomendasi pada konsultan sebagai dasar penilaian yang akan dilaksanakan oleh dewan penilai. Berdasarkan hasil penilaian terhadap persyaratan administratif PPKBLUD diperoleh nilai total sebesar 87,90 . Dengan perolehan nilai tersebut maka status yang direkomendasikan untuk RSUD Brebes adalah "BLUD PENUH", dengan kriteria memuaskan.

\section{Dukungan Stakeholder}

a. Dukungan stakeholder internal

Berdasarkan hasil wawancara dan telaah dokumen diketahui bahwa RSUD Brebes sudah melaksanakan langkahlangkah persiapan sejak tahun 2007, dan sekarang sudah sampai pada tahap penilaian oleh dewan penilai. Langkahlangkah persiapan tersebut diantaranya adalah membentuk tim BLUD RSUD Brebes, mengikuti bintek BLUD, studi banding, pendampingan penyusunan persyaratan administratif dengan BPKP Provinsi Jawa Tengah, advokasi dan sosialisasi dengan Pemda/Legislatif, membentuk dewan penilai BLUD RSUD Brebes dan pembekalan dewan penilai oleh konsultan BLUD dari UGM. Kondisi saat ini dokumen persyaratan administratif sudah direvisi dan sudah dilakukan penilailan oleh dewan penilai. Selanjutnya direncanakan akan dilaksanakan peninjauan ke lapangan oleh dewan penilai, terkait pelaksanaan standar pelayanan minimal (SPM) RSUD Brebes.

RSUD Brebes sudah menggunakan aplikasi instrumen pendukung pengelolaan manajemen pelayanan pasien dan keuangan yaitu sistem informasi manajemen rumah sakit (SIMRS) dengan sistem billingnya, namun dalam pelaksanaannya masih perlu dilakukan penyempurnaan agar operasionalisasinya dapat optimal. SIMRS ini merupakan sarana prasarana pendukung yang mutlak harus ada jika mekanisme PPK-BLUD diterapkan. Adanya budaya kerja yang kurang inovatif dan cenderung bersifat rutinitas, struktur organisasi dan tata kerja (SOTK) pada saat itu kurang responsif terhadap dinamika peningkatan dan pengembangan pelayanan rumah sakit, menunjukkan adanya indikasi lemahnya sistem kerja organisasi RSUD Brebes. SOTK yang ada pada tahun 2007 terdiri dari dua bagian struktural yaitu Subbag Keuangan dan Subbag Kesekretariatan. Hal ini menyebabkan semua permasalahan operasionalisasi pelayanan rumah sakit tertumpu pada direktur. Pada awal tahun 2009 dilakukan restrukturisasi organisasi dengan job design yang sudah dianalisis bersama oleh stakeholder internal dan diyakini dapat mengakomodir secara komprehensif pengelolaan sistem manajemen RSUD Brebes. Tetapi disisi lain potensi sumber daya manusia yang ada kurang responsif dan kreatif terhadap perubahan struktur organisasi dan tupoksi yang telah dijabarkan dengan menyesuaikan konsep pengembangan layanan RSUD Brebes arah ke depan. Beberapa hal tersebut di atas merupakan faktor penyebab terhambatnya proses pembentukan PPK-BLUD RSUD Brebes. Menurut Haris (2005), sistem kerja, motivasi dan pembelajaran pegawai sangat berpengaruh dalam membangun kondisi yang memungkinkan pemberdayaan pegawai secara penuh dan selaras dengan 
tujuan serta rencana tindakan organisasi secara menyeluruh.

b. Dukungan stakeholder eksternal

Rumah sakit harus menjamin bahwa proses-proses pendukung utama dirancang untuk memenuhi seluruh operasional internal dan persyaratan pelanggan. Merujuk pada hasil penelitian, proses pendukung belum diidentifikasi dan ditujukan pada kebutuhan dan strategi pasar bagi pelanggan sesuai dengan visi dan misi rumah sakit. Berdasarkan hasil observasi dan telaah dokumen diketahui bahwa sumber daya keuangan berasal dari APBD, APBN dan dana dekonsentrasi. RSUD Brebes ditargetkan pendapatannya sebagai PAD Kabupaten Brebes, sehingga kewenangan pengelolaan pendapatan operasional pelayanan RS sepenuhnya diatur oleh Pemda Brebes. Dengan adanya pembatasan ini, maka fungsi bisnis RSUD Brebes menjadi sangat lemah.

Dari hasil wawancara secara formal maupun informal diperoleh informasi bahwa pada prinsipnya Pemda Brebes sangat mendukung adanya transformasi RSUD Brebes dari Satuan Kerja Perangkat Daerah menjadi BLUD dengan tujuan peningkatan kualitas pelayanan kepada masyarakat. Hal ini dibuktikan dengan antusiasme mereka untuk mengikuti pembekalan dewan penilai selama tiga hari yang diselenggarakan oleh pihak RSUD Brebes, dengan mengundang konsultan BLUD dari UGM. Media ini juga bertujuan untuk menyamakan persepsi kedua belah pihak tentang hal-hal terkait dengan kebijakan BLUD RSUD Brebes sebagai provider pelayanan kesehatan rujukan milik Pemda Brebes.

\section{Faktor-faktor yang berpengaruh}

a. Faktor-faktor pendorong

Berdasarkan hasil wawancara dengan informan Direktur dan Ketua Komite Medik diketahui bahwa wacana awal pembentukan PPK-BLUD RSUD Brebes adalah dari Direktur RSUD Brebes pada tahun 2007. Dengan langkah-langkah persiapan yang telah dilakukan menunjukkan bahwa Direktur pada saat itu mempunyai komitmen tinggi terhadap organisasi untuk membawa perubahan ke arah kemajuan. Secara kuantitas ketersediaan sumber daya dan sistem kerja cukup memadai untuk mendukung transformasi sistem manajemen ke arah PPK-BLUD. Adanya tenaga medis paramedis dengan jumlah sesuai standar RS tipe C, SOTK dengan job design yang dinilai cukup responsif dan dapat mengakomodir sistem pelayanan komprehensif RS, sistem remunerasi, aplikasi sistem informasi manajemen rumah sakit (SIMRS), kelengkapan sarana prasarana yang memenuhi syarat, dukungan Pemda terhadap kemudahan regulasi terkait penerapan PPK-BLUD, dan gaya kepemimpinan kreatif dan inovatif Direktur RS menjadi faktor pendorong pencapaian target proses perubahan paradigma sistem pengelolaan keuangan RSUD Brebes saat ini. Dikatakan oleh John P. Kotter, (1996) bahwa langkah awal penting dan menentukan dalam memimpin perubahan adalah dengan melakukan perubahan dalam diri dan perilaku pemimpin, termasuk memperkuat kompetensi kepemimpinannya.

b. Faktor-faktor penghambat

SOTK RSUD Brebes kurang didukung oleh penempatan personil yang benar-benar mempunyai integritas, profesionalisme dan kompetensi di bidangnya, sehingga hal ini mengakibatkan terhambatnya proses akselerasi penerapan PPK-BLUD RSUD Brebes. Seiring proses evaluasi terhadap penempatan pejabat struktural, Pemda Brebes saat ini sudah melakukan penataan kembali personil dalam SOTK RSUD Brebes dengan melantik pejabat baru dan memutasikan pejabat lama ke instansi lain. Namun kondisi faktual di lapangan, pergantian posisi personil tersebut belum berpengaruh secara signifikan terhadap kualitas kinerja pelayanan RSUD Brebes. Sebagai institusi milik Pemda, RSUD Brebes merupakan organisasi pelayanan kesehatan yang mempunyai tingkat kompleksitas tinggi karena di dalamnya padat modal, padat teknologi dan padat karya sehingga kondisi ini seringkali 
menyebabkan timbulnya conflict of interest antar unit di dalamnya. Kondisi lingkungan kerja yang ada di RSUD Brebes tentunya membutuhkan kemampuan pengelolaan manajemen yang tangguh untuk dapat mengelola sumber daya yang ada, dimana tujuan akhirnya adalah peningkatan kinerja pelayanan kesehatan kepada masyarakat. Mengacu pada hasil penelitian, remunerasi di RSUD Brebes menjadi suatu bentuk reward atas kinerja pegawai, namun implementasi saat ini sistem remunerasi belum berbasis kinerja sehingga hal ini juga berimplikasi terhadap kepuasan kerja pegawai. Dalam rangka perubahan ke arah PPK-BLUD, sistem remunerasi sudah dilakukan beberapa perbaikan dengan menggunakan pola kompensasi yang lebih menekankan pada kinerja pegawai.

Pengelolaan keuangan yang mengacu pada mekanisme APBD sering menjadi hambatan dalam implementasi kegiatan RSUD Brebes. Adanya pembatasan kewenangan pengelolaan keuangan dan kewajiban menyetorkan seluruh pendapatan yang diperoleh RSUD

\section{KESIMPULAN DAN SARAN}

\section{Kesimpulan}

Persyaratan untuk mendapatkan status PPK-BLUD RSUD Brebes, sudah seluruhnya memenuhi standar yang ditetapkan dalam Permendagri nomor 61 tahun 2007 tentang petunjuk teknis pengelolaan keuangan BLUD.

Pemda dan Legislatif Kabupaten Brebes sangat mendukung terhadap kesiapan RSUD Brebes menuju BLUD, dengan tercapainya kesepakatan untuk segera melaksanakan penilaian persyaratan administratif oleh dewan penilai BLUD RSUD Brebes.

Faktor-faktor yang mendukung kesiapan RSUD Brebes menuju PPK-BLUD adalah proses kepemimpinan di RSUD Brebes dalam tahap awal pembaharuan ke arah perbaikan kinerja, adanya komitmen tinggi Direktur terhadap organisasi untuk membawa perubahan ke arah kemajuan, ketersediaan sumber daya (dana, sarpras, ke kas daerah, maka sudah dapat dipastikan bahwa fungsi bisnis RS sebagai penyelenggara jasa layanan kesehatan mutlak tidak dapat diaplikasikan. Aturan birokrasi membelenggu dan mematikan daya inovatif RS untuk mengembangkan layanan core bisnisnya. Hal ini jelas akan berdampak negatif pada kelancaran operasionalisasi pelayanan, dan sangat sulit bagi RSUD untuk dapat meningkatkan kualitas pelayanannya. Beberapa faktor penghambat ini perlu mendapatkan perhatian khusus oleh pemimpin RSUD Brebes pada saatnya sudah menerapkan PPK-BLUD, karena hal ini tentunya akan menjadi masalah yang serius jika tidak segera ditangani dan nantinya akan mengganggu pengelolaan sistem manajemen RSUD Brebes yang baru. Sebagai institusi milik Pemda yang menghasilkan pendapatan dari hasil produk jasa layanannya dan memberikan kontribusi yang cukup besar terhadap PAD, sudah semestinya Pemda Brebes mendukung proses transformasi menuju BLUD.

SDM) dan sistem kerja cukup memadai untuk mendukung transformasi sistem manajemen ke arah PPK-BLUD, adanya dukungan stakeholder internal diwujudkan dengan melakukan serangkaian langkahlangkah persiapan internal organisasi, advokasi dan sosialisasi dengan Pemda/Legislatif.

Faktor-faktor yang menghambat kesiapan RSUD Brebes menuju PPK-BLUD adalah seringnya terjadi suksesi Direktur menyebabkan proses akselerasi menuju PPK-BLUD beberapa kali mengalami kondisi stagnasi, adanya SOTK yang kurang di dukung oleh penempatan personil yang benar-benar mempunyai integritas, profesionalisme dan kompetensi di bidangnya, pengelolaan keuangan yang mengacu pada mekanisme APBD sering menjadi hambatan dalam implementasi kegiatan RSUD Brebes. Hal ini tentunya akan mengancam eksistensi RSUD Brebes 
untuk melangkah kepada perubahan sistem pola pengelolaan keuangan yang baru yaitu PPK-BLUD.

\section{Saran}

RSUD Brebes perlu melakukan pendekatan secara sistematis terhadap proses pengukuran kinerja, analisis dan manajemen pengetahuan yaitu dengan menggunakan sistem manajemen balance scorecard yang efektif untuk diaplikasikan.

Persyaratan administratif yang sudah disusun perlu dilakukan evaluasi dalam kurun waktu tertentu untuk disesuaikan dengan perkembangan situasi pangsa pasar, kemajuan era globalisasi dan perkembangan teknologi.

RSUD Brebes perlu segera melakukan advokasi dan konsolidasi kepada Pemda dan Legislatif terkait subsidi APBD,

\section{Referensi}

Ansyar, 2001. Analisis Kesiapan Puskesmas untuk menjadi Puskesmas Swadana di Kota Bengkulu. Tesis Pasca Sarjana IKM Universitas Gadjah Mada.

Arikunto, S., 2005. Manajemen Penelitian. Jakarta: PT Rineka Cipta.

Depkes RI., 1994. Buku Pedoman Upaya Peningkatan Mutu Pelayanan Rumah Sakit (Konsep Dasar dan Prinsip). Jakarta: Dirjen Yanmedik, Depkes RI.

Depkes RI., 2003. Pedoman Akuntansi Rumah Sakit Jakarta: Depkes RI.

Dinkes Brebes, 2008. Profil Kesehatan Kabupaten Brebes tahun 2008. Brebes: Dinkes Brebes.

Duncan, W.J., Ginter, P.M., Swayne, L.E., 1996. Strategic Managementof Health Care Organizations Second Edition. Massachusetts USA: Blackwell Business Publishers Inc. Cambridge.

Haris, A., 2005. Pilar Perusahaan Unggul Implementasi Kriteria Baldrige untuk Meningkatkan Kinerja Perusahaan. Jakarta: PT Gramedia Pustaka Utama.

Hasan, I. 2002. Pokok-pokok Materi Metodologi Penelitian dan Aplikasinya: Ghalia Indonesia. untuk mewujudkan capacity building organisasi menuju eksistensi dan peningkatan kinerja pelayanan kesehatan kepada masyarakat sebagai muara dari penerapan PPK-BLUD rumah sakit.

Pemda Brebes dan Legislatif harus segera melakukan peninjauan ulang terhadap penetapan pagu APBD dan peruntukannya untuk RSUD Brebes, untuk menjamin dan menjaga eksistensi operasionalisasi pelayanan menuju market follower.

Diperlukan penelitian lanjutan untuk membuktikan secara kualitatif dan kuantitatif mengenai penilaian mutu kinerja organisasi dengan menggunakan pendekatan instrumen manajemen kualitas yang aplikatif untuk pengembangan organisasi pelayanan kesehatan khususnya rumah sakit.

Ikhsan, A., 2010. Akuntansi Dan Manajemen Keuangan Rumah Sakit. Edisi Pertama. Yogyakarta: Graha IImu.

Kotler, P., 2005. Manajemen Pemasaran. Edisi Bahasa Indonesia. Jakarta: PT Indeks Kelompok Gramedia.

Kusnanto, H . Metode Kualitatif dalam Riset Kesehatan . Yogyakarta: Aditya Media.

Miles, MB . Huberman, AM., 1992. Analisis Data Kualitatif Buku Sumber tentang Metode-Metode Baru. Jakarta: Universitas Indonesia (UI Press).

Muninjaya, GAA ., 2004. Manajemen Kesehatan, edisi 2. Jakarta: Buku Kedokteran EGC.

Muninjaya, GAA., 2004. Survey Kepuasan Pengguna Jasa Pelayanan Kesehatan Perjan Rumah Sakit Sanglah Denpasar. Jurnal Manajemen Pelayanan Kesehatan The Indonesian Journal of Health Service Management, Vol 07 (03) September: pp. 115-122.

Nasution, MP., 2004. Kemandirian Pengelolaan Keuangan di Rumah Sakit Pemerintah Reformasi Manajemen Keuangan Badan Layanan Umum. Arsada. Vol 21 Agustus 2004. 
Notoatmodjo, S., 2005. Metodologi Penelitian Kesehatan, Cetakan Ketiga. Jakarta: PT Rineka Cipta.

Parsan, 2005. Analisis Kesiapan Dinas Kesehatan Dalam Mengalokasikan Anggaran Kesehatan di Kabupaten Muna Propinsi Sulawesi Tenggara pada Era Desentralisasi, Tesis Pasca Sarjana IKM Universitas Gadjah Mada.

http://www.djpk.depkeu.go.id., dikunjungi Januari 2010., Peraturan Pemerintah (PP) No.23 Tahun 2005, tentang Pengelolaan Keuangan Badan Layanan Umum (BLU).

http://www.depdagri.go.id., dikunjungi Februari 2010., Peraturan Menteri Dalam Negeri (Permendagri) No.61 Tahun 2007, tentang Pedoman Teknis Pengelolaan Keuangan Badan Layanan Umum (BLU).

RSUD Brebes, 2004. Renstra Bisnis RSUD Brebes Tahun 2007-2012. Brebes: RSUD Brebes.

Ristrini, 2005. Perubahan Paradigma Jasa Pelayanan Kesehatan Rumah Sakit dan Rekomendasi Kebijakan Strategis bagi Pemimpin, Jurnal Manajemen Pelayanan Kesehatan The Indonesian Journal of Health Service Management, 08 (01) Maret, pp. 3-8.

RSUD Brebes, 2008. Laporan Keuangan RSUD Brebes Tahun 2008. Brebes: RSUD Brebes.
RSUD Brebes, 2008. Laporan Keuangan RSUD Brebes Tahun 2009. Brebes: RSUD Brebes.

Soeroso, S., 2003. Manajemen Sumber Daya Manusia di Rumah Sakit Suatu Pendekatan Sistem, Penerbit Buku Kedokteran EGC, Jakarta.

Trisnantoro, L., 2004. Memahami Penggunaan IImu Ekonomi dalam Manajemen Rumah Sakit, cetakan kedua, Gadjah Mada University press.

Trisnantoro, L., 2005. Aspek Strategis Manajemen Rumah Sakit Antara Misi Sosial dan Tekanan Pasar, Yogyakarta: Andi.

Trisnantoro, L., 2005. Kepemimpinan di Rumah Sakit dalam Konteks Governance di Sektor Kesehatan: Implikasi terhadap Pengembangan Para Pemimpin. Buletin Arsada II (02), pp.13-15 Jakarta.

Thabrany, H., 2005. Rumah Sakit Publik Berbentuk BLU: Bentuk Paling Pas Dalam Koridor Hukum Saat ini. Manajemen dan Administrasi Rumah Sakit Indonesia, VI (1) Pebruari, pp.921.

Yin, K.R., 2003. Studi Kasus Desain dan Metode. Jakarta: PT Raja Grafindo Persada. 